\title{
DDoS Attack Prevention and Mitigation Techniques - A Review
}

\author{
Deepika Mahajan \\ Shaheed Bhagat Singh State Technical Campus, \\ Ferozpur, Punjab, India
}

\author{
Monika Sachdeva \\ Shaheed Bhagat Singh State Technical Campus, \\ Ferozpur, Punjab, India
}

\begin{abstract}
The present era is completely dependent on Internet. Internet serves as a global information source for all users, so the availability of internet is very important. In this paper the main focus is on the DDoS attack which hinders the network availability by flooding the victim with high volume of illegitimate traffic usurping its bandwidth, overburdening it to prevent legitimate traffic to get through. Various techniques to prevent and mitigate these attacks along with their advantages and disadvantages are also discussed.
\end{abstract}

\section{General Terms}

DDoS Attack, Flooding Attack, Distributed, Attacker

Keywords

DDoS attack, Availability, Zombie, Botnet.

\section{INTRODUCTION}

The internet in simple terms is defined as an interconnected system of computer networks. The scope of internet in day to day life is vast; it provides a wide range of information, services, resources which allows all sectors to be well linked As the need of internet is growing with time, various issues related to its security comes insight. The reason for internet insecurity is basically its design because foremost concern was its functionality rather than its security. Hence several types of attacks and threats are reason for apprehension towards security of internet. The issues related to internet security are authentication, integrity, availability, confidentiality and non- repudation. In this paper main focus is on insecurity to availability, availability means that the information, the computing systems, and the security controls are all accessible and operable in committed state at some random point of time [1]. Among all attacks DDoS (Distributed Denial of service) attacks are those which hinder clients, users to access all advantages of services available to them from server side. DDoS attack results in long system timeouts, lost revenues, large volumes of work to identify attacks and to prepare adequate response measures [23] Denial of service (DoS) attack is Distributed Denial of service (DDoS) attack since it is launched concurrently to numerous machines. DDos attacks are not new disturbance to internet, they came back late in August 1999 and after that incessantly their severity is growing. Some recognized DoS attacks are SYN Flood, teardrop, smurf, ping of death [2]. There have been large scale attacks targeting many high profile websites $[26,27,28]$. These sites include twitter, facebook, Amazon etc. There are varieties of DDoS attacks as classified in [16, 17]. However, the most common form of DDoS attacks is a packet-flooding attack, in which a large number of seemingly legitimate TCP, User Datagram Protocol (UDP), or Internet Control Message Protocol (ICMP) packets are directed to a specific destination. DDoS attacks cannot be detected and stopped easily because forged source addresses and other techniques are used to conceal attack sources [29]. As per
Peng et al. [19], protection against these attacks is challenging for mainly two reasons. First, the number of zombies involved in a DDoS attack is very large and exploitation of these zombies spans large geographical areas. The volume of traffic sent by a single zombie might be small, but the volume of aggregated traffic arriving at the victim host is overwhelming. Second, zombies usually spoof their IP addresses under the control of attacker, which makes it very difficult to trace the attack traffic back even to zombies. In this paper an overview of DDoS attack and various prevention and mitigation techniques for DDos attacks along with their advantages and disadvantages is discussed.

\section{OVERVIEW OF DDOS ATTACK}

A denial-of-service attack is regarded as an attempt to prevent the legitimate use of a service. A distributed denial-of-service attack differs from DoS attack as it deploys multiple attacking entities to attain this goal. One frequently exercised manner to perform a DDoS attack is for the attacker to send a stream of packets to a victim; this stream consumes some key resource, thus rendering it unavailable to the victim's legitimate clients. Another common approach is for the attacker to send a few malformed packets that confuse an application or a protocol on the victim machine and force it to freeze or reboot [17]. DDoS attack causes a failure of service to users, loss of network connectivity and facility by consuming the bandwidth of the victim network or overloading the computational resources of the victim system.

DDoS attack does not rely on particular network protocol or system weakness. It simply exploits the huge resource asymmetry between the Internet and the victim [3]. Since Internet architecture is open in nature, any machine attached to it is publically visible to another machines attached to enable the communication. The hacker or attacker community takes the unhealthy advantage of this open nature to discover any insecure machine connected to the Internet. The discovered machine is thus infected with the attack code. The infected machine can further be used to discover and infect another machine connected and so on. The attacker thus gradually prepares an attack network. Depending upon the attacking code the hackers send control instructions to masters which in turn control agents. The zombies under the control of masters transmit attack packets which converge at victim to exhaust its resources. DDoS attack basically targets victim's computational or communicational resources [18], such as bandwidth, memory, CPU cycle, file descriptors and buffers etc. The recruit phase is very first phase in occurrence of DDoS attack in which the attacker discovers the vulnerability in the victim system and recruit multiple agents, these multiple agents also called as bots or zombie. These zombies form a botnet including all such negotiated machines which are responsible to run attack code under common command and control by the attacker. The second phase is the exploit phase in which the vulnerability is exploited in the recruited zombies. The third phase known as infect phase bots are 
infected with the attack code. Last phase is the use phase which uses the agents to send the attack code to victim system.

Mirkovic et al. [17] have classified DDOS attacks into two broad categories: flooding attacks and vulnerability attacks. Flooding DDoS attacks consume resources such as network bandwidth. These attacks flood the network with such a high volume of traffic which consumes their available network resources are and legitimate user requests cannot get through, resulting in degraded productivity. Vulnerability attacks use the expected behavior of protocols such as TCP and HTTP to the attacker's advantage. Connectivity attacks flood a computer with such a high volume of connection requests, that all available operating system resources are consumed and the computer can no longer process legitimate user requests [25]. However, resources of connecting network are not a problem in case of commercial servers as these are hosted by the ISPs. But server resources such as processing capacity, buffer limit etc., are put under stress by flood of seemingly legitimate requests generated by DDoS attack zombies. Each request consumes some CPU cycles. Once the total request rate is more than the service rate of server, the requests start getting buffered in the server, and after some time due to buffer over run, incoming requests are dropped. The congestion and flow control signals force legitimate clients to decrease their rate of sending requests, whereas attack packets keep coming. Finally, a stage comes when only attack traffic is reaching at the server. Thus, service is denied to legitimate clients [2]. Robinson et al. [20] stated that as attack strength grows by using multiple sources, the computational requirements of even filtering traffic of malicious flows become a burden at the target.

\section{DDOS DEFENSE}

DDoS defense means to relieve victim's resources from high volume of fake packets sent by attackers from disseminated locations, so that these resources could be used to serve legitimate users. The distributed nature of DDoS attacks make them enormously difficult to combat. Attackers may also use IP spoofing to conceal their identity. There is no satisfactory security in comparison to persistent security breaches in the Internet. DDoS defense mechanism consists of prevention, detection, tolerance and mitigation and response.

According to, Douligeris et al. [16]Attack prevention aims to fix security holes, such as insecure protocols, weak authentication schemes and vulnerable computer systems, which can be used as stepping stones to launch a DoS attack. This approach aims to improve the global security level and is the best solution to DoS attacks. Various methods of prevention are ingress filtering, egress filtering, route based packet-filtering, history based IP-filtering. Detection means a host computer and a network can guard themselves against being a source of network attack as well as being a victim of a DDoS attack either by using the database of known signatures or by recognizing anomalies in system behaviors. It is impossible to completely stop DDoS attacks, so mitigation and tolerance is important. The impact of attack can be minimized through fault tolerance or increasing quality of service. The table 1 [11-15] and [21-24] underneath discusses various prevention techniques and table 2 [4-9] discusses various mitigation and tolerance techniques to combat DDoS attacks.
Table 1. DDoS prevention Techniques

\begin{tabular}{|c|c|c|c|}
\hline $\begin{array}{c}\text { Name of } \\
\text { Technique }\end{array}$ & $\begin{array}{l}\text { Approach } \\
\text { Used }\end{array}$ & Advantage & Disadvantage \\
\hline $\begin{array}{l}\text { Ingress } \\
\text { Filtering }\end{array}$ & $\begin{array}{l}\text { Ingress Router } \\
\text { set to drop } \\
\text { traffic with IP } \\
\text { address not } \\
\text { matching to } \\
\text { domain prefix. }\end{array}$ & $\begin{array}{l}\text { Reduces } \\
\text { DoS attack } \\
\text { due to IP } \\
\text { spoofing, } \\
\text { locates } \\
\text { source of } \\
\text { attack if } \\
\text { ISP's have } \\
\text { ingress } \\
\text { filtering } \\
\text { instead of } \\
\text { customer } \\
\text { links }\end{array}$ & $\begin{array}{l}\text { It just reduces, } \\
\text { does not } \\
\text { prevent use of } \\
\text { forged source } \\
\text { address of } \\
\text { another host } \\
\text { within } \\
\text { permitted } \\
\text { prefix filter } \\
\text { range. }\end{array}$ \\
\hline $\begin{array}{l}\text { Egress } \\
\text { Filtering }\end{array}$ & $\begin{array}{l}\text { Makes certain } \\
\text { that only } \\
\text { assigned IP } \\
\text { address } \\
\text { space leaves } \\
\text { the network. } \\
\text { Outbound } \\
\text { filter is used. }\end{array}$ & $\begin{array}{l}\text { Protects } \\
\text { other } \\
\text { domain } \\
\text { from } \\
\text { possible } \\
\text { attack }\end{array}$ & $\begin{array}{c}\text { There is } \\
\text { wastage of } \\
\text { resources of } \\
\text { domain where } \\
\text { packet } \\
\text { originates }\end{array}$ \\
\hline $\begin{array}{c}\text { Route Based } \\
\text { Distributed } \\
\text { Packet } \\
\text { Filtering }\end{array}$ & $\begin{array}{l}\text { Uses routing } \\
\text { information. It } \\
\text { works on basis } \\
\text { that for every } \\
\text { link in } \\
\text { internet, there } \\
\text { is limited } \\
\text { number of } \\
\text { source IP } \\
\text { addresses from } \\
\text { which traffic } \\
\text { comes. }\end{array}$ & $\begin{array}{l}\text { Synergistic } \\
\text { filtering } \\
\text { effect is } \\
\text { possible, } \\
\text { spoofed IP } \\
\text { flows are } \\
\text { prevented } \\
\text { from } \\
\text { reaching } \\
\text { other } \\
\text { Autonomo } \\
\text { us } \\
\text { Systems. }\end{array}$ & $\begin{array}{l}\text { Difficult to } \\
\text { update route- } \\
\text { based filters in } \\
\text { real time. } \\
\text { Acquiring } \\
\text { global } \\
\text { knowledge of } \\
\text { whole } \mathrm{n} / \mathrm{w} \\
\text { topology has } \\
\text { scalability } \\
\text { issues }\end{array}$ \\
\hline $\begin{array}{l}\text { History } \\
\text { Based IP- } \\
\text { Filtering }\end{array}$ & $\begin{array}{l}\text { A pre-built IP } \\
\text { address } \\
\text { database is } \\
\text { used and an } \\
\text { edge router } \\
\text { acknowledges } \\
\text { the incoming } \\
\text { packets } \\
\text { accordingly. }\end{array}$ & $\begin{array}{l}\text { It is robust, } \\
\text { there is no } \\
\text { need of } \\
\text { studying } \\
\text { the whole } \\
\text { network } \\
\text { topology }\end{array}$ & $\begin{array}{l}\text { If the invader } \\
\text { knows that the } \\
\text { IP packet filter } \\
\text { is based on } \\
\text { prior } \\
\text { connections, } \\
\text { they might } \\
\text { deceive the } \\
\text { server to be } \\
\text { included in the } \\
\text { IP address } \\
\text { database. }\end{array}$ \\
\hline $\begin{array}{l}\text { Secure } \\
\text { Overlay } \\
\text { Services } \\
\text { (SOS) }\end{array}$ & $\begin{array}{l}\text { Hash based } \\
\text { routing is } \\
\text { used, the user } \\
\text { traffic is } \\
\text { authenticated } \\
\text { via SOAP then } \\
\text { traffic is } \\
\text { routed though } \\
\text { small number } \\
\text { of nodes called } \\
\text { as servlets to } \\
\text { victim. }\end{array}$ & $\begin{array}{l}\text { Distributed } \\
\text { system that } \\
\text { offers } \\
\text { exceptional } \\
\text { protection } \\
\text { to the } \\
\text { specified } \\
\text { target at } \\
\text { the cost of } \\
\text { modifying } \\
\text { client } \\
\text { systems. }\end{array}$ & $\begin{array}{l}\text { Not } \\
\text { recommended } \\
\text { for public } \\
\text { servers. }\end{array}$ \\
\hline $\begin{array}{c}\text { Load } \\
\text { Balancing }\end{array}$ & $\begin{array}{l}\text { Simple } \\
\text { approach that } \\
\text { enables } \\
\text { network } \\
\text { providers to }\end{array}$ & $\begin{array}{l}\text { In a } \\
\text { multiple- } \\
\text { server } \\
\text { architectur } \\
\text { e the }\end{array}$ & $\begin{array}{l}\text { It is costly and } \\
\text { complex. }\end{array}$ \\
\hline
\end{tabular}




\begin{tabular}{|c|c|c|c|}
\hline & $\begin{array}{l}\text { increase the } \\
\text { provided } \\
\text { bandwidth on } \\
\text { critical } \\
\text { connections } \\
\text { and prevent } \\
\text { them from } \\
\text { going down in } \\
\text { the event of an } \\
\text { attack. }\end{array}$ & $\begin{array}{l}\text { balance of } \\
\text { the load is } \\
\text { necessary } \\
\text { so that both } \\
\text { the } \\
\text { improveme } \\
\text { nt of } \\
\text { normal } \\
\text { performanc } \\
\text { e. }\end{array}$ & \\
\hline $\begin{array}{l}\text { Honey } \\
\text { pot }\end{array}$ & $\begin{array}{l}\text { Allow the } \\
\text { attacker to } \\
\text { attack the } \\
\text { honypot and } \\
\text { not the actual } \\
\text { system; they } \\
\text { also help to } \\
\text { gain info of } \\
\text { the attacker by } \\
\text { storing their } \\
\text { records, the } \\
\text { type of attack } \\
\text { and type of } \\
\text { software used. }\end{array}$ & $\begin{array}{l}\text { Main goal } \\
\text { is to make } \\
\text { attacker } \\
\text { think that } \\
\text { he has } \\
\text { compromis } \\
\text { ed the } \\
\text { machine(h } \\
\text { oneypot) as } \\
\text { slave and } \\
\text { understand } \\
\text { the attack } \\
\text { code, this } \\
\text { helps to } \\
\text { detect the } \\
\text { attacker }\end{array}$ & $\begin{array}{l}\text { Assumes that } \\
\text { the attack must } \\
\text { be detectable } \\
\text { using signature } \\
\text { based } \\
\text { detection tools. }\end{array}$ \\
\hline
\end{tabular}

Table 2. DDoS Mitigation and Tolerance Techniques

\begin{tabular}{|c|c|c|c|}
\hline $\begin{array}{l}\text { Name of } \\
\text { Technique }\end{array}$ & $\begin{array}{l}\text { Approach } \\
\text { Used }\end{array}$ & Advantage & Disadvantage \\
\hline $\begin{array}{l}\text { Integrated } \\
\text { Intserv }\end{array}$ & $\begin{array}{l}\text { Uses the } \\
\text { Resource } \\
\text { Reservation } \\
\text { Protocol } \\
\text { (RSVP) to } \\
\text { manage the } \\
\text { resources } \\
\text { allocation } \\
\text { along the path } \\
\text { that a } \\
\text { particular } \\
\text { traffic passes. }\end{array}$ & $\begin{array}{l}\text { The } \\
\text { bandwidth } \\
\text { and buffer } \\
\text { space for a } \\
\text { particular } \\
\text { link is } \\
\text { assured for } \\
\text { specific } \\
\text { traffic flow }\end{array}$ & $\begin{array}{l}\text { Due to pre } \\
\text { allocation of } \\
\text { resources their } \\
\text { consumption } \\
\text { increases. }\end{array}$ \\
\hline $\begin{array}{c}\text { Differentiated } \\
\text { Services }\end{array}$ & $\begin{array}{l}\text { Based on } \\
\text { Type of } \\
\text { Service byte } \\
\text { in IP header }\end{array}$ & $\begin{array}{c}\text { Allocates } \\
\text { resources } \\
\text { based on } \\
\text { TOS of } \\
\text { incoming } \\
\text { packet }\end{array}$ & $\begin{array}{c}\text { Requires } \\
\text { cooperation of } \\
\text { multiple } \\
\text { administrative } \\
\text { domains. }\end{array}$ \\
\hline $\begin{array}{c}\text { Class Based } \\
\text { Queuing }\end{array}$ & $\begin{array}{l}\text { Queues for } \\
\text { different type } \\
\text { of packets and } \\
\text { different } \\
\text { packets } \\
\text { for different } \\
\text { type of service } \\
\text { is set, } \\
\text { bandwidth is } \\
\text { assigned to } \\
\text { queues }\end{array}$ & $\begin{array}{c}\text { Maintains } \\
\text { QoS } \\
\text { during } \\
\text { DDoS } \\
\text { attack }\end{array}$ & $\begin{array}{c}\text { It is difficult to } \\
\text { maintain } \\
\text { queues. }\end{array}$ \\
\hline
\end{tabular}

\begin{tabular}{|c|c|c|c|}
\hline $\begin{array}{l}\text { Resource } \\
\text { Pricing }\end{array}$ & $\begin{array}{l}\text { propose a } \\
\text { distributed } \\
\text { gateway } \\
\text { architecture } \\
\text { and a payment } \\
\text { protocol that } \\
\text { imposes } \\
\text { dynamically } \\
\text { changing } \\
\text { prices on both } \\
\text { network, } \\
\text { server, and } \\
\text { information } \\
\text { resources }\end{array}$ & $\begin{array}{l}\text { They } \\
\text { identify } \\
\text { allotting a } \\
\text { priority } \\
\text { mechanism } \\
\text { to desirable } \\
\text { clients as } \\
\text { being key, } \\
\text { and punish } \\
\text { clients that } \\
\text { cause load } \\
\text { on the } \\
\text { server. }\end{array}$ & $\begin{array}{l}\text { Malicious user } \\
\text { can populate } \\
\text { the system with } \\
\text { fake requests at } \\
\text { low price, thus } \\
\text { driving up the } \\
\text { price for } \\
\text { legitimate } \\
\text { users. }\end{array}$ \\
\hline PushBack & $\begin{array}{l}\text { First, a local } \\
\text { Aggregate } \\
\text { Congestion } \\
\text { Control } \\
\text { (ACC) detects } \\
\text { the congestion } \\
\text { at the router } \\
\text { level and } \\
\text { devises an } \\
\text { attack } \\
\text { signature. The } \\
\text { signature } \\
\text { defines a } \\
\text { traffic } \\
\text { aggregate as a } \\
\text { group of } \\
\text { traffic flows } \\
\text { with a } \\
\text { common } \\
\text { property } \\
\text { Then, a } \\
\text { local ACC } \\
\text { determines an } \\
\text { appropriate } \\
\text { rate limit for } \\
\text { this aggregate. }\end{array}$ & $\begin{array}{c}\text { PushBack } \\
\text { can } \\
\text { effectively } \\
\text { mitigate } \\
\text { DDoS } \\
\text { attacks } \\
\text { when the } \\
\text { attacker's } \\
\text { machines } \\
\text { are } \\
\text { gathered in } \\
\text { few places. }\end{array}$ & $\begin{array}{l}\text { When attackers } \\
\text { are widely } \\
\text { distributed } \\
\text { over the } \\
\text { Internet, the } \\
\text { legitimate } \\
\text { traffic also is } \\
\text { rate-limited } \\
\text { and PushBack } \\
\text { will not be } \\
\text { successful. }\end{array}$ \\
\hline Throttling & $\begin{array}{l}\text { Traffic } \\
\text { passing } \\
\text { through the } \\
\text { router to the } \\
\text { source is rate } \\
\text { limited to the } \\
\text { throttle rate. } \\
\text { only } \\
\text { aggressive } \\
\text { flows which } \\
\text { do not respect } \\
\text { their rate } \\
\text { shares are } \\
\text { punished and } \\
\text { not other } \\
\text { flows. This } \\
\text { method } \\
\text { is still in the } \\
\text { experimental } \\
\text { stage. }\end{array}$ & $\begin{array}{l}\text { Prevents } \\
\text { servers } \\
\text { from going } \\
\text { down. Eg: } \\
\text { web } \\
\text { servers }\end{array}$ & $\begin{array}{l}\text { Difficult to } \\
\text { implement } \\
\text { throttling, hard } \\
\text { to decipher } \\
\text { legitimate } \\
\text { traffic from } \\
\text { malicious } \\
\text { traffic. In the } \\
\text { process of } \\
\text { throttling, } \\
\text { legitimate } \\
\text { traffic may } \\
\text { sometimes be } \\
\text { dropped or } \\
\text { delayed and } \\
\text { malicious } \\
\text { traffic may be } \\
\text { allowed to pass } \\
\text { to server. }\end{array}$ \\
\hline
\end{tabular}




\section{CONCLUSION}

In this paper, an apparent vision of the DDoS attack is attained and discussed numerous techniques along with their pros and cons to prevent and alleviate these attacks. Due to an alarming increase in DDoS attacks, internet security from these attacks becomes vulnerable issue. Having clarified view of the attack, effective countermeasures can be implemented to fight against these attacks.

\section{REFERENCES}

[1] Tipton H. and Krause M. 2004, Information Security Management Handbook, CRC Press.

[2] Sachdeva M., Singh G., Kumar K. and Singh K. 2010. DDoS incidents and their impact: A review, International Arab Journal of Information Technology, vol. 7, Issue 1, pp. 14-19.

[3] Chang R.K.C. 2002. Defending against flooding-based distributed denial-of-service attacks: A Tutorial, Computer Journal of IEEE Communication Magazine, vol. 40, Issue 10, pp. 42-51.

[4] Yau D.K., Lui J.C.S., Liang F. 2002. Defending Against Distributed Denial of Service attacks with max-min fair server-centric router throttles, in: Proceedings of the Tenth IEEE International Workshop on Quality of Service (IWQoS), Miami Beach, FL, pp. 35-44.

[5] Zhao W., Olshefski D., Schulzrinne H. 2000. Internet Quality of Service: an overview, Columbia Technical Report CUCS-003-00.

[6] Blake S., Black D., Carlson M., Davies E., Wang Z., Weiss W. 1998. An architecture for differentiated services, in: IETF, RFC 2475.

[7] Geoffrey M.B., Xie G. 2002. A feedback mechanism for mitigating Denial of Service attacks against differentiated services clients, In Proceedings of the 10th International Conference on Telecommunications systems, Monterey, CA, pp. 204-213.

[8] Ioannidis J., Bellovin S.M. 2002. Implementing pushback: router-based defense against DDoS Attacks. In Proceedings of Network and Distributed System Security Symposium, (NDSS), San Diego, CA, pp. 6-8.

[9] Mankins S.M., Sangpachatanaruk C., Znati T., Melhem R., Moss D. 2003. Proactive server roaming for mitigating Denial of Service attacks. In Proceedings of 1st International Conference on Information Technology Research and Education (ITRE), Newark, NJ, USA, August 10-13,

[10] Kargl F., Maier J., Weber M. 2001. Protecting web servers from Distributed Denial of Service attacks. In Proceedings of the Tenth International Conference on World Wide Web, Hong Kong, pp. 514-524.

[11] Ferguson P., Senie D. 2001. Network ingress filtering: defeating Denial of Service attacks which employ IP source address spoofing. In RFC 2827.

[12] Global Incident analysis Center-Special NoticeEgress filtering, Available from <http://www.sans.org/y2k/egress.htm>.

[13] Park K., Lee H. 2001. On the effectiveness of routebased packet filtering for Distributed DoS attack prevention in powerlaw Internets, In Proceedings of the ASIGCOMM_01 Conference on Applications, Technologies, Architectures, and Protocols for Computer Communications, ACM Press, New York, pp. 15-26.

[14] Peng T., Leckie C., Ramamohanarao K. 2003. Protection from Distributed Denial of Service attack using history- based IP filtering. In Proceedings of IEEE International Conference on Communications, Anchorage, AL, USA.

[15] Keromytis A., Misra V., Rubenstein D. 2002. SoS: secure overlay services. In Proceedings of the ACM SIGCOMM_02 Conference on Applications, Technologies, Architectures, and Protocols for Computer Communications, ACM Press, New York, pp. 61-72.

[16] Douligeris C. and Mitrokotsa A. 2004. DDoS Attacks and Defense Mechanisms: Classification and State of the Art, Computer Journal of Networks, vol. 44, Issue 5, pp. 643-666.

[17] Mirkovic J., and Reiher P. 2004, A taxonomy of DDoS attack and DDoS defense mechanisms, Computer Journal of ACM SIGCOMM, vol. 34, Issue 2, pp. 39-53.

[18] Kumar K., Joshi R., and Singh K. 2006, An integrated approach for defending against distributed denial of service attacks, IIT Madras. [Online]. Available: http://www.cs.iitm.ernet.in/ iriss06/paper.html.

[19] Peng T., Leckie C., and Ramamohanarao K. 2007, Survey of Network Based Defense Mechanism Countering the DoS and DDoS Problems, Computer Journal of ACM Computing Surveys, vol. 39, Issue 1, pp. 123-128.

[20] Robinson M., Mirkovic J., Schnaider M., Michel,S., and Reiher P. 2003, Challenges and Principles of DDoS Defense, Computer Journal of ACM SIGCOMM, vol. 5, Issue 2, pp. 148-152.

[21] Lee R.B., Taxonomies of Distributed Denial of Service networks, attacks, tools and countermeasures, Princeton University, Available from $<$ http://www.ee.princeton.edu/ rblee>.

[22] Weiler N. 2002. Honeypots for Distributed Denial of Service, In Proceedings of the Eleventh IEEE International Workshops Enabling Technologies: Infrastructure for Collaborative Enterprises 2002, Pitsburgh, PA, USA, pp. 109-114.

[23] Golubev V. 2005. DoS attacks: crime without penalty[Online]. Available: http://www.crime- research.org/ articles/1049/

[24] Sardana A., Joshi R. 2009. An auto-responsive honeypot architecture for dynamic resource allocation and QoS adaptation In DDoS attacked network, Computer Communication on Heterogeneous Networking for Quality, Reliability, Security, and Robustness - Part II Elsevier, vol. 32, Issue 12, pp. 1384- 1399.

[25] Stein L.D., Stewart J.N. 2002. The World Wide WebSecurity FAQ, version 3.1.2, Available from <http://www.w3.org/Security/Faq>.

[26] CERT Coordination Center, Denial of Service attacks, Available<http://www.cert.org/tech_tips/denial_of_servi ce.html>.

[27] Computer Security Institute and Federal Bureau of Investigation 2001, CSI/FBI Computer crime and security survey, CSI, Available from <http://www.gocsi. com>.

[28] Moore D., Voelker G., Savage S. 2001. Inferring Internet Denial of Service activity, In Proceedings of the USENIX Security Symposium, Washington, DC, USA , pp. 9-22.

[29] Yuan J., Mills K. 2005. Monitoring the macroscopic effects of DDoS flooding Attack, IEEE Transactions on Dependable and secure computing, vol. 2, Issue. 4, pp 324-335. 